NBER WORKING PAPER SERIES

\title{
STRICT DOLLARIZATION AND ECONOMIC PERFORMANCE: AN EMPIRICAL INVESTIGATION
}

\author{
Sebastian Edwards \\ I. Igal Magendzo \\ Working Paper 9820 \\ http://www.nber.org/papers/w9820
NATIONAL BUREAU OF ECONOMIC RESEARCH 1050 Massachusetts Avenue Cambridge, MA 02138
July 2003

We have benefited from discussions with John Cochrane, Barry Eichengreen, Eduardo Engel, Ed Leamer, Robert Barro, Lars Svensson, Hans Genberg and Andy Rose. The views expressed herein are those of the authors and not necessarily those of the National Bureau of Economic Research

(C)2003 by Sebastian Edwards and I. Igal Magendzo. All rights reserved. Short sections of text not to exceed two paragraphs, may be quoted without explicit permission provided that full credit including $($ ) notice, is given to the source. 
Strict Dollarization and Economic Performance: An Empirical Investigation

Sebastian Edwards and I. Igal Magendzo

NBER Working Paper No. 9820

July 2003

JEL No. F30, F31

\section{$\underline{\text { ABSTRACT }}$}

In this paper we analyze the macroeconomic record of "strictly dollarized" economies. In particular, we investigate whether dollarized countries have historically exhibited faster growth and lower volatility than countries with a domestic currency. We analyze this issue by using a treatment regression analysis that estimates jointly the probability of being a dollarized country, and outcome equations. Our analysis indicates that the probability of being a dollarized country depends on regional, geographical, political and structural variables. Our results also suggest GDP per capita growth has not been statistically different in dollarized and in non-dollarized ones. We also find that volatility has been significantly higher in dollarized than in non-dollarized economies. These results are robust to the estimation technique, and to the sample used.

Sebastian Edwards

Anderson Graduate School of Business

University of California, Los Angeles

110 Westwood Plaza, Suite C508

Box 951481

Los Angeles, CA 90095-1481

and NBER

sebastian.edwards@anderson.ucla.edu
I. Igal Magendzo

Central Bank of Chile

and Universidad de Chile

imagendzo@bcentral.cl 


\section{Introduction}

A number of authors have recently argued that (some) emerging nations should give up their domestic currency, and adopt an advanced nation's currency as legal tender. This policy option has received the generic name of "official dollarization," even if the advanced country's currency is other than the dollar.

There is wide agreement among economists that countries that give up their currency, and delegate monetary policy to an advanced country's (conservative) central bank, will tend to have lower inflation than countries that pursue an active domestic monetary policy. Indeed, dollarization allows these countries to deal with the inflationary-bias associated with monetary institutions that lack credibility. ${ }^{1}$ Recent empirical analyses provide broad support to this hypothesis. Work by Engel and Rose (2002), Boegitc (2000), Eichengreen and Hausman (1999), Edwards (2001) and Edwards and Magendzo (2003) has found that dollarized and currency union countries have had a significantly lower rate of inflation than countries with a domestic currency.

There is much less agreement, however, on the effects of dollarization on real economic variables, such as growth, employment and volatility. According to its supporters, dollarization will positively affect growth through two channels: First, dollarization will tend to result in lower interest rates, higher investment and faster growth (Dornbusch 2001). And second, by eliminating currency risk, a common currency is supposed to encourage international trade; this, in turn, will result in faster growth. Rose (2000), and Rose and Van Wincoop (2001), among others, have emphasized this trade channel. Other authors, however, have been skeptical regarding the alleged benefits of dollarization. Indeed, according to a view that goes back at least to Meade (1950), countries with a hard peg - including dollarized countries - will have difficulties accommodating external shocks, including terms of trade and world interest rate disturbances. This, in turn, will be translated into greater instability and, under some circumstances, may even lead to lower economic growth (Fischer 1976; Parrado and Velasco, 2002). Frankel (1999) has taken an intermediate position, arguing that there is no unique recipe on exchange rate policy; while some countries will benefit from hard

\footnotetext{
${ }^{1}$ See, for example, Cooper and Kempf (2001), Alesina and Barro (2000), Calvo (1999), and Eichengreen and Hausmann (1999).
} 
pegs, for other countries a floating regime will be more appropriate. According to him, the answer to the dollarization question will depend on the type of structural variables discussed by Mundell (1961) in his classical article on optimal currency areas.

Eichengreen (2001) has taken an even more pragmatic view, and has argued that the evidence on the relationship between monetary regimes and growth is largely inconclusive, and does not support the claim that the exchange rate regime is an important determinant of growth.

What is surprising about this debate, however, is that there have been very few empirical comparative analyses on economic performance under dollarized monetary regimes. Indeed, most cross-country studies on the subject have focused on "independent currency unions," and have included very few observations on strictly dollarized countries. For instance, the Engel and Rose (2002) data set includes 26 countries that do not have a currency of their own, and have data on real GDP per capita. Of these, only seven use another nation's currency, and only two -- Panama and Puerto Rico -- use a convertible currency as legal tender, and are thus "strictly dollarized" countries. ${ }^{2}$ The comprehensive study on exchange rate regimes, growth, and inflation by Gosh et al (1995), does not include nations that do not have a currency of their own. The IMF (1997) study on alternative exchange rate systems excluded dollarized countries and the recent paper by Levy-Yeyeti and Sturzenegger (2001) on exchange rates and economic performance did not include nations that do not have a central bank. It is not an exaggeration to say that until recently, most existing evidence on dollarization was based on the experience of Panama, a country that has used the US dollar as legal tender since $1904 .^{3}$

The purpose of this paper is to analyze empirically the historical macroeconomic record of strictly dollarized economies. ${ }^{4}$ More specifically, we are interested in investigating whether dollarization is associated with superior macroeconomic performance, as measured by faster GDP growth and lower GDP growth volatility. The

2 This is also the case of the influential paper by Frankel and Rose (2002).

${ }^{3}$ Goldfjan and Olivares (2001) use econometrics to evaluate Panama's experience with dollarization. Moreno-Villalaz (1999) provides a detailed analysis of the Panamanian system. Bogetic (2000) describes several aspects of dollarization in a number of countries. As far as we know, Engel and Rose (2002) and Edwards (2001) are the first two papers to provide a statistical and econometric analysis of economic performance in dollarized countries and/or currency unions. 
reason for focusing on strictly dollarized countries is rather simple: to a large extent the policy debate in the emerging world is whether these countries ought to adopt an "advanced" country's currency, as a way of achieving credibility. For Argentina, for instance, it is very different to delegate the running of monetary policy to the Federal Reserve, than delegating it to a MERCOSUR central bank that would be run by Brazilians and Argentines. Argentine politicians and economists rightly ask whether the latter would have any more credibility than their own embattled Central Bank. ${ }^{5}$

Comparing economic performance in dollarized countries and in countries with a currency of their own is not an easy task, however. The problem is how to define an appropriate "control" group with which to compare the dollarized nations. In this paper we tackle this issue by using a treatment regressions technique that estimates jointly the probability of being a dollarized country, and outcome equations on GDP per capita growth and on growth volatility. ${ }^{6}$

Our analysis on the probability of a country being strictly dollarized relies on two strands of literature: the optimal currency areas literature pioneered by Mundell (1961), and the literature on the political economy of exchange rate and currency regimes. Scholars working on political economy have recently focused on two issues that are closely related to the subject of this paper. First, some authors have argued that the adoption of hard pegs has little to do with achieving credibility and low inflation; instead it responds to politicians interests in generating superior performance in terms of real economic variables (Frieden 2002, 2003). The results reported in this paper provide information on whether strictly dollarized regimes have indeed generated stronger (real) performance than countries with a domestic currency. Second, Bernhard et al. (2002) and Freeman (2002), among others, have recently argued that it is important to analyze jointly episodes where hard pegs and central bank independence reinforce themselves as "credibility enhancing" institutions. The analysis of growth and volatility performance under strict dollarization provides a unique opportunity for analyzing the experience of a group of countries that have done precisely this. Indeed, dollarization is an extreme

\footnotetext{
${ }^{4}$ In Edwards and Magendzo (2003) we investigate the case of all types of currency unions.

${ }^{5}$ For an analysis of independent currency unions see, for example, Edwards and Magendzo (2002).
} 
monetary regime where the country has the hardest of hard pegs, and where central bank independence from local politicians is complete - after all, monetary policy is fully delegated to foreigners.

Our analysis differs from other related work in this general area in several respects. First, we have made an effort to include data on a large number of strictly dollarized countries. This has not been easy, as most strictly dollarized countries are very small and their data are not included in readily available data sets. After significant effort we were able to obtain data on GDP per capita growth and inflation for 20 strictly dollarized countries. Our data set, then, is significantly more general than the data set used by other researchers, including Rose and Engel (2002). Second, we focus directly on two of the most important real macroeconomic variables - real GDP per capita growth, and growth volatility. Other studies, in contrast, have analyzed performance in an indirect fashion, and have focused on ancillary variables such as the level of international trade and/or interest rates. For instance, Frankel and Rose (2002) have analyzed the way in which currency unions affect bilateral trade, while Edwards (1999), and Powel and Sturzenegger (2003) have investigated the way in which the exchange rate/monetary regime affects interest rate behavior and the cost of capital. ${ }^{7}$ Third, and as pointed out earlier, our empirical approach allows us to estimate jointly the probability of being a "strictly dollarized country" and the effect of dollarization on two outcome variables. Fourth, we explicitly introduce political economy considerations into the analysis. That is, we investigate whether, as suggested by credibility-based models, countries with an inflationary "propensity" have a higher probability of being strictly dollarized. ${ }^{8}$ And finally, in order to check for the robustness of the results we also use non-parametric matching techniques.

The rest of the paper is organized as follows: In Section II we provide a preliminary analysis of historical experiences with "dollarization.” In Section III we use "treatment regressions" to analyze the effects of "dollarization" on GDP per capita

\footnotetext{
6 Ideally, we would have liked to include consumption volatility. Unfortunately, many of the small dollarized countries do not have data on consumption. On treatment regression models see, for example, Maddala (1983), Green (2000) and Wooldridge (2002).

7 See Klein (2002) for a discussion on dollarization and trade, including a comprehensive bibliography on the subject.
} 
growth and volatility. In Section IV we deal with extensions and with robustness. We investigate whether different samples and estimation techniques affect the results. In particular, we report results on comparative performance obtained from an analysis that uses "matching estimators." Finally in Section V we provide some concluding remarks.

\section{Strict Dollarization During 1970-1998}

Countries that use a foreign convertible currency as legal tender may be divided into two groups: The first one corresponds to independent nations, while the second group includes territories, colonies or regions within a national entity. Panama is an example of the first group, while Puerto Rico belongs to the second group. Table 1 contains a list of countries and territories that have had an official dollarized system at any time during the 1970-1998 period, and that have data on key macroeconomic variables such as inflation and GDP growth. ${ }^{9}$ These countries are very small indeed, and many are city-states well integrated into their neighbors' economies - Monaco, Liechtenstein, and Andorra are good examples. In fact, many of the dollarized economies are so small that they do not have data on basic economic indicators such as inflation or growth.

As may be seen from Table 1, we have been able to collect data on GDP per capita growth for 20 dollarized countries and territories. There are a number of other very small countries with dollarized monetary systems, which don't have data on economic performance. Some of these are: Vatican City, Coco Island, Guam, Niue, Norfolk Island, North Marianas, Pitcairn, Saint Helena, Tokelau and the Turks \& Caicos. For a complete list see Edwards and Magendzo (2001). Notice that in spite of the fact that we only have 20 countries, our data set is significantly larger than those used by other researchers. For example, and as we pointed out in the introduction, in the Rose and Engel (2002) and Frankel and Rose (2002) data sets there are only two strictly dollarized countries. Most of their sample is comprised of "independent currency union" countries (See Edwards and Magendzo 2003, for an analysis of currency unions.)

\footnotetext{
8 For discussions on the political economy of exchange rate regimes see, for example, Persson and Tabellini (2000).

9 We follow the U.S. Congress' Joint Economic Committee, and concentrate on those territories that have a high degree of administrative autonomy. There are some borderline cases, however, that may generate some controversies.
} 
The largest independent dollarized countries in Table 1 are Liberia and Panama. Only the latter, however, remains dollarized today. ${ }^{10}$ The vast majority of the countries in Table 1 are extremely open, and in most of them there are no controls on capital mobility or on any type of financial transactions. So much so, that as recently as 2001 six out of the 14 independent dollarized nations in Table 1 were in the OECD's list of "Unfair Tax Havens," or countries whose financial regulations allegedly allow individuals and corporations to evade taxes. These fundamental characteristics of the dollarized economies - very small and extremely open - already suggest that using a broad control group of all non-dollarized countries, which are much larger and not as open, may indeed generate biased results. ${ }^{11}$ Finally, only one country in Table 1 has switched monetary regimes within the timeframe of our sample. In 1982 Liberia abandoned dollarization, when the government of President Samuel Doe decided to issue local currency as a way of avoiding the constraints imposed on macroeconomic policy by the lack of a domestic currency. This means that it is not possible to perform an empirical analysis based on a diffs-in-diffs methodology. ${ }^{12}$

\section{Dollarization and Real Macroeconomic Performance: The Evidence}

\section{III.1 The Empirical Model}

Our main interest is to undertake a comparative analysis on the conditional effect of a "dollarization" on real macroeconomic performance. In order to do this, we estimate jointly an "outcome equation" and an equation on the probability of being a dollarized country. More specifically, we consider two outcome variables: GDP per capita growth and growth volatility. ${ }^{13}$ The data set covers 1970 through 1998, and includes 169 counties

\footnotetext{
${ }^{10}$ Liberia abandoned the use of the U.S. dollar in 1982. See Edwards and Magendzo (2003).

11 The median population of all non-dollarized emerging nations is over 100 times larger than that of the dollarized economies.

12 In the last few years some countries have dollarized, including Ecuador in 2000 and El Salvador in 2001.

${ }^{13}$ In principle, the monetary/exchange rate regime will affect the growth process - both the first and second moments -- through three potential channels. First, a lower cost of capital - usually associated with dollarized economies --, will result in a higher rate of physical capital accumulation and a higher rate of growth of potential output. Second, a high level of international trade - which, as Rose and his coauthors have persuasively shown is associated with common currency regimes - is likely to have a positive effect on TFP growth, and on the rate of GDP growth. This effect has been emphasized in a number of endogenous growth models, and operates through the effect of openness on the accumulation of knowledge. And third, since the exchange rate regime will affect the country's ability to accommodate
} 
and territories. There are 3,966 observations on growth per capita. When using 5 years averages - both in the growth and volatility models - the panel has 720 observations. ${ }^{14}$ Countries with a currency union -- such as the CFA countries in Africa --, are excluded from the analysis).

The empirical model is given by equations (1) through (4):

$$
\begin{aligned}
& \mathrm{y}_{\mathrm{jt}}=\mathbf{x}_{\mathrm{jt}} \beta+\gamma \delta_{\mathrm{j}}+\mu_{\mathrm{jt}} \\
& \delta_{\mathrm{jt}}= \begin{cases}1, & \text { if } \delta^{*}{ }_{\mathrm{jt}}>0 \\
0, & \text { otherwise }\end{cases}
\end{aligned}
$$

$$
\delta{ }{ }_{\mathrm{jt}}=\mathbf{w}_{\mathbf{j t}} \alpha+\varepsilon_{\mathrm{jt}} .
$$

Equation (1) is the macroeconomic performance or outcome equation, where $\mathrm{y}_{\mathrm{j}} \mathrm{t}$ stands for each of the macroeconomic outcome variables of interest in country $j$ and period $t ; \mathbf{x}_{\mathbf{j}}$ $\mathbf{t}$ is a vector of covariates that capture the role of traditional determinants of economic performance. $\delta_{\mathrm{j} t}$ is a dummy variable (i.e. the treatment variable) that takes a value of one if country $\mathrm{j}$ in period $\mathrm{t}$ is "strictly dollarized" country, and zero if the country has a currency of its own. $\mu_{\mathrm{jt}}$ is an error term, whose properties are discussed below. $\beta$ and $\gamma$ are parameters to be estimated. The common currency dummy is assumed to be the result of an unobserved latent variable $\delta^{*}{ }_{j}$, as described in equation (2). $\delta^{*}{ }_{j}$, in turn, is assumed to depend linearly on vector $\mathbf{w}_{\mathbf{j}}$ t . Some of the variables in $\mathbf{w}_{\mathbf{j}} \mathbf{t}$ may be included

external terms of trade shocks, it will affect growth volatility and, possibly, average growth. Indeed, if as Dornbusch (1982) and Corden (2002), have argued, countries with a hard peg - including strictly dollarized countries -- have more difficulties accommodating external disturbances, they will tend to exhibit, on average, a lower and more volatile rate of growth than countries with a domestic currency.

\footnotetext{
${ }^{14}$ The volatility variable is measured as the standard deviation of growth over a five year period. When alternative 7-year periods were used, there were no significant changes in the results.
} 
in $\mathbf{x}_{\mathbf{j} \mathbf{t}}$ (Maddala 1983, p. 120). ${ }^{15} \alpha$ is a parameters vector to be estimated, and $\varepsilon_{\mathrm{j}}$ is an error term. Error terms $\mu_{\mathrm{j} t}$ and $\varepsilon_{\mathrm{jt}}$ are assumed to be bivariate normal, with a zero mean and a covariance matrix given by:

$$
\left(\begin{array}{ll}
\sigma & \varsigma \\
\varsigma & 1
\end{array}\right)
$$

If the performance and dollarization equations are independent, the covariance term $\varsigma$ in equation (4) will be zero. Under most plausible conditions, however, it is likely that this covariance term will be different from zero.

As shown by Greene (2000), the log likelihood for observation k is:

$$
\begin{aligned}
& L_{k}=\log \Phi\left\{\frac{w_{k} \alpha+\left(y_{k}-x_{k} \beta-\delta\right) \varsigma / \sigma}{\sqrt{1-\varsigma^{2}}}\right\}-\frac{1}{2}\left\{\frac{y_{k}-x_{k} \beta-\delta}{\sigma}\right\}^{2}-\log \sqrt{2 \pi} \sigma, \\
& \quad \text { if } \delta_{k}=1 \\
& L_{k}=\log \Phi\left\{\frac{-w_{k} \alpha-\left(y_{k}-x_{k} \beta\right) \varsigma / \sigma}{\sqrt{1-\varsigma^{2}}}\right\}-\frac{1}{2}\left\{\frac{y_{k}-x_{k} \beta}{\sigma}\right\}^{2}-\log \sqrt{2 \pi} \sigma, \\
& \text { if } \delta_{k}=0 .
\end{aligned}
$$

If equation (1) is estimated by least squares, the treatment effect will be overestimated -- see Greene (2000, p. 934). In this paper we use a two step procedure to estimate the model in equations (1) through (4). In the first step, the treatment equation (2) is estimated using probit regressions. From this estimation a hazard is obtained for each $\mathrm{j}, \mathrm{t}$ observation. In the second step, the outcome equation (1) is estimated with the hazard added as an additional covariate. From the residuals of this augmented outcome regression, it is possible to compute consistent estimates of the variance-covariance matrix (4) (See Maddala 1983, and Wooldridge 2002 for details).

15 It is assumed, however, that $\delta *_{\mathrm{jt}}$ does not depend on $\mathrm{y}_{\mathrm{j} t}$. Otherwise, as discussed below, the model 
The model in equations (1) - (4) will satisfy the consistency and identifying conditions of mixed models with latent variables if the outcome variable $\mathrm{y}_{\mathrm{j}} \mathrm{t}$ is not a determinant of the treatment equation -- that is, if $\mathrm{y}$ is not one of the variables in $\mathrm{w}$ in equation (3). ${ }^{16}$ For the case under study this is a reasonable assumption. Although the initial level of GDP per capita may affect the probability of being a dollarized country, its rate of change, or the second moment of its rate of change is unlikely to have an impact on the decision of having a domestic currency. See Maddala (1983), Heckman (1978), Angrist (2000) and Wooldridge (2002) for further discussions on these issues. As is clear in the discussion that follows, in the estimation of the model (1)-(4) we impose a number of exclusionary restrictions; that is, a number of variables in vector $\mathbf{w}_{\mathbf{j}} \mathbf{t}$ are not included in vector $\mathbf{x}_{\mathbf{j}} \mathbf{t}$

\section{III.2 Basic Results}

In this section we report the results obtained from the estimation of the treatment effects model given by equations (1) through (4). We proceed as follows: We first discuss the specification used for the first-stage probit equation on the probability of being a dollarized country. An important feature of this analysis is that we explicitly use a "credibility index" as a (possible) determinant of this probability. We then discuss the specification for both outcome equations on GDP per capita growth and on growth volatility. Finally, we present the results from the (joint) estimation of both models. In Section IV we deal with extensions and with robustness issues.

\section{III.2.1 Equation Specification}

a. The Treatment Equation: In specifying the treatment equation (3) on the probability of being a dollarized country, we draw on two interrelated bodies of work: (1) optimal currency areas analyses; and (2) the political economy of exchange rate regimes. In a highly influential article, Mundell (1961, p. 181) argued that the "optimum currency area is the region." By this he meant that regional considerations - geographical proximity and the existence of factor mobility, among other - were more important than national (or sovereign) considerations in determining optimal currency areas. This regional-based approach has been present in most subsequent work on the subject of

${ }^{16}$ Details on identification and consistency of models with mixed structures can be found in Maddala (1983). See, also, Heckman (1978) and Angrist (2000). 
optimal currency areas. ${ }^{17}$ Following Mundell's insight, we include a number of "regional variables" in our empirical analysis on the probability of being a "dollarized" country. More specifically, in the specification of the treatment equation (3), we included the following covariates that encapsulate the importance of the "region:" (a) a dummy variable that takes the value of one if the economy in question is an independent nation, and zero if it is a territory. Since factor mobility is much lower across independent nations than between a dependent territory and the "home country", we expect the coefficient of this variable to be negative in the estimation of equation (3). ${ }^{18}$ (b) A dummy variable that takes the value of one if the country has a common border with a nation whose currency the IMF defines as a "convertible currency." We call this variable "border," and we expect its estimated coefficient to have a positive sign in equation (3). (c) In some specifications we also used a dummy variable that takes the value of one if the country in question is an island or archipelago. Since island-archipelago countries are relatively isolated, they tend to be self-contained regions. We expect this variable to have a negative coefficient in (3).

The political economy literature, on the other hand, has emphasized both credibility and distributive issues. From a credibility perspective, countries that give up their domestic currency are countries that are willing to "tie their hands." These are usually countries where temptation to inflate is significant, and/or countries whose monetary institutions lack credibility (Person and Tabellini, 2000). Frieden (2003) has argued that from a distributive perspective, politically powerful groups will try to influence the selection of the exchange rate regime in a way that benefits their interests. According to Frieden (2003), since dollarization eliminates currency risk, this regime will have a high degree of political support in countries with a large external sector and a high degree of openness (See also Freeman 2002, and Bernhard et al 2002). Based on these views, in the estimation of the treatment equation we also included two political economy covariates: (d) an index that captures the credibility motive for dollarizing. This index was constructed as a composite of institutional, structural and economic variables that affect the authorities' decision to "tie their hands" (see the Appendix to this paper for the

\footnotetext{
${ }^{17}$ See Alesina, Barro and Tenreyro (2002) for a recent discussion on the subject.

${ }^{18}$ As Mill (1848) pointed out, whether a country is independent is also a political economy variable, as nations usually affirm their sovereignty by having a currency of their own.
} 
details). ${ }^{19}$ We called this index credibility. Its sign to be negative, as higher numbers reflect a higher degree of credibility. (e) An indicator of the degree of openness of the economy; as suggested by Frieden (2003), among others, we expect its estimated coefficient sign to be positive. For the majority of countries we used the Sachs and Warner (1995) openness index. We used data from a variety of sources to supplement the Sachs-Warner index for those countries and years not covered in their sample. ${ }^{20}$

In addition to these regional and political economy variables ${ }^{21}$, the following covariates were also included in the specification of the treatment equation (3): (f) the $\log$ of population measured in millions of people, as an index of the country's size. We expect the estimated coefficient of this variable to be negative, indicating that larger countries are less likely to use another nation's currency. (g) The log of initial (1970) GDP, taken as a measure of the country's economic size. We also expect the coefficient of this variable to be negative. And, (h) a variable that measures the (log of the) distance between each country and global markets; in defining this "distance variable" we followed Leamer (1997). We expect its estimated coefficient to be negative indicating that countries that are less integrated to world markets will have a lower probability of being common currency countries.

b. The Outcome Equations: Our analysis focused on two outcome variables: (a) GDP per capita growth, (b) growth volatility. A difficulty we faced in undertaking this analysis is that most of the "dollarized" countries have limited data availability. For instance, almost none of the strictly dollarized countries have data on education attainment or on some other variables traditionally included in growth empirical analyses (Barro and Sala-I-Martin 1995, Barro, 1996). Indeed, popular data sets, such as the World Bank WDI, the IFS or the Barro-Lee (1996) data set, include data on only a

\footnotetext{
${ }^{19}$ More specifically, we used two alternative methods to construct the credibility index: principal components and a regression-based index. The variables used to construct both versions of the the credibility index are: legal origin of institutions, years since independence, political instability (instability), a dummy for exporters of non-fuel primary products, and "neighborhood inflation." See the appendix for details. Results for both indexes were qualitatively identical and quantitatively very similar. We present only the index constructed using principal components. The alternative index was built as the fitted value of a regression of inflation on the variables specified above. The correlation between both indexes was 0.89 .

20 See the original Sachs-Werner (1995) article for a specific list of requirements for a country to qualify as "open."

${ }^{21}$ Unfortunately, there are no available data on other regional variables of interest, including a generalized index of factor mobility or of synchronicity of shocks, for all countries in our sample.
} 
handful (three or four) strictly dollarized countries. Nevertheless, and after searching in a number of alternative data sources, we were been able to include a number of covariates in the outcome equations (1) for per capita growth, and volatility. ${ }^{22}$ In the estimation of the GDP growth model we included, as customary, initial GDP, a measure of openness, a variable that captures the country's geographical location, regional dummies (no dummies were included for Asia, which is defined as the reference region), ${ }^{23}$ and the "common currency" dummy. As Sachs (2000), among others, has argued, countries located close to the equator tend to grow more slowly than nations in other parts of the world. Our geography variable -- which we call "tropics"-- is defined as the (normalized) absolute distance from each country to the equator ${ }^{24}$. We expect its coefficient to be negative, capturing the fact that, with other things constant, countries closer to the tropics will tend to grow at a slower rate than countries in other geographical areas. ${ }^{25}$

In the volatility model we include the following covariates in the outcome equation: initial GDP, openness, the regional dummies and the dollarization dummy. As in the growth models, in some of the specifications we introduced regional dummy variables. A number of factors suggest that the poorer countries have a limited capacity to absorb external shocks - they lack well developed domestic capital markets, have limited access to international borrowing and their exports are concentrated in a small number of commodities. Consequently, in the volatility model we expect that the estimated coefficient of initial GDP to be negative. Frenkel and Razin (1987), among others, have suggested that external shock will get amplified in countries that are relatively closed to international trade. According to their intertemporal models, more open economies will tend to have a lower degree of volatility. Thus, we expect that the coefficient of openness will be negative in the volatility models.

\section{III.2.2 Main Results}

In Table 2 we summarize the results obtained from the estimation of treatment models for GDP per capita growth and for growth volatility. The table contains two panels. The upper panel includes the results from the outcome equation; the lower panel

${ }^{22}$ The data are available from the authors on request.

${ }^{23}$ These variables are expected to capture the effect of some of variables for which there were no data.

${ }^{24}$ According to this definition, the equator receives a value of zero and the poles a value of -1 . 
contains the estimates for the "treatment equation." As pointed out above, the treatment countries corresponds to the strictly dollarized countries in Table 1, and the untreated group is comprised of all countries with a currency of their own. In Section IV, however, we report results for the case where the untreated group is formed by countries with a pegged regime.

Probability of Being a Common Currency Country The results are reported in the lower panel for two sample sizes: a 3,966-observation sample, and a 720-observation data set of five years averages. As may be seen, the results are similar across models and are quite satisfactory. The majority of the coefficients have the expected signs, and are statistically significant at conventional levels. These results indicate that the probability of being a "dollarized" country is higher for very small, not independent countries (i.e. territories), that are also very open. Sharing a border with a country with a convertible currency increases the probability of being a dollarized country, while distance is not a significant determinant of this probability. ${ }^{26}$ As may be noted, the estimated coefficient of the credibility index is significantly negative, indicating that countries with higher levels of macroeconomic credibility will be less prone to tying their hands through the adoption of a hard peg and dollarization.

GDP per Capita Growth and Growth Volatility: Models 1 through 3 in Table 2 are for the growth model. We report results from three systems: the first two were estimated using annual data, while the third was estimated using five-year averages. As may be seen, the traditional regressors have the expected signs and are significant at conventional levels: initial GDP has a negative coefficient suggesting that there is "conditional convergence;" openness has a positive coefficient indicating that more open economies have tended to exhibit a higher rate of GDP growth. The "tropics" variable has an only marginally significant negative coefficient, confirming that geography plays an important role in the growth process. In terms of the exchange rate regime, these results show that the coefficient of the "dollarization" dummy is positive, but not

\footnotetext{
${ }^{25}$ See Leamer (1997) and Venables et al. (2002) for discussions on the role of geography and distance on economic growth.

${ }^{26}$ In addition to the variables in tables 3-6, we considered additional covariates. In particular, we constructed an index on whether the country in question was a member of a "deep" trading area. This index, however, identifies almost fully the "common currency" countries, reducing the spirit of the analysis.
} 
statistically significant in any of the specifications. This indicates that, during the period under consideration, and after controlling for other factors, countries with a "strictly dollarized" regime have not performed differently, in terms of GDP growth per capita, than countries with a currency of their own. These results provide some evidence against the claim, made by dollarization supporters, that dollarized countries tend to grow faster than countries with a currency of their own.

Models 4 and 5 in Table 2 refer to volatility. As may be seen, the dummy variable for "strict dollarization" is significantly positive, indicating that countries without a domestic currency have experienced a higher degree of volatility than countries with a currency of their own. The point estimates of these dummies (2.1 and 2.8) are significantly higher than the simple mean difference of volatility in dollarized and nondollarized countries - that simple difference is 0.8 and not statistically significant. With regard to the other covariates, the results in Table 2 confirm our prior that openness reduces volatility - a result that is in line with a number of theoretical results in international economics. ${ }^{27}$ In addition, our estimates indicate that, after controlling by other factors, countries with a higher initial level of GDP per capita have had a somewhat higher degree of volatility (the point estimate of this coefficient is, however, rather low). Also, countries that are closer to the equator have exhibited a higher degree of volatility. The estimates of the regional dummies, indicate that growth in the countries of the Middle East (MENA) has been particularly volatile. The dummy for Eastern and Central Europe is positive, although not significant.

\section{Further Results and Robustness Analysis}

In this section we investigate the robustness of the results both with respect to estimation methods as well as samples.

\section{IV.1 Non-Parametric Methods}

It is possible that the specification forms chosen for the outcome equations affect the results reported above. In particular, the linearity of these equations may affect the estimates of the "treatment coefficient." In order to investigate whether this is an important factor, we undertook a non-parametric analysis based on "matching estimators" (see Blundell and Costa-Dias 2000). A general advantage of this non-parametric method

27 See Frenkel and Razin (1987). 
is that no particular specification of the underlying model has to be assumed. Matching estimators pair each common currency country with countries from the with-domesticcurrency group. ${ }^{28}$ If the sample is large enough, for each treated (common currency) observation we can find, in principle, at least one untreated observation with exactly the same characteristics. Each of these properly selected untreated observations provides the required counterfactual for our comparative analysis. ${ }^{29}$ The problem is that under most general conditions it is not possible to find an exact match between a treated and untreated observation. The matching estimator method focuses on estimating an average version of the parameter of interest. ${ }^{30}$ That is, the matching estimator consists of obtaining the difference in outcome as an average of the differences with respect to "similar" -- rather than identical -- untreated outcomes. Rosenbaum and Rubin (1983) have shown that an efficient and simple way to perform this comparison is to rely on a propensity score, defined as the probability of participation or treatment: $P(x)=\operatorname{Prob}(D=1 / x)$. In our case, this is the probability of a country being a strictly dollarized country. This reduces a multi-dimensional problem to a one-dimensional problem, provided that we can estimate $P(x)$. Instead of matching countries directly on all of their characteristics, we can compare countries with similar probability of being a strictly dollarized country. An additional advantage of this method is that the estimation of the treatment on the treated is not affected by the lack of data on some of the other variables affecting the outcome. In that regard, then, this method provides us with an

\footnotetext{
${ }^{28}$ If we estimate the equation above using all non-treated observations the selection bias is given by: $B(x)=E\left(u_{0} / x, D=1\right)-E\left(u_{0} / x, D=0\right)$.

${ }^{29}$ In order to guarantee that all treated agents have such a counterpart in the population (not necessarily in the sample) we also need to assume that $0<\operatorname{Pr} o b(D=1 / x)<1$.

${ }^{30}$ This averaged version is given by:

$M(S)=\frac{\int_{S} E\left(y_{1}-y_{0} / x, D=1\right) d F(x / D=1)}{\int_{S} d F(x / D=1)}$,
}

where $\mathrm{S}$ is a subset of the support of $x$ given $D=1$. 
elegant way of handling potential problems emanating from omitted variables in the outcome equations. $^{31}$

In this section we report results obtained from using a simple-average nearest neighbor estimator. According to this method, for each treated observation, we select a pre-determined number of untreated nearest neighbor(s). The nearest neighbors of a particular treated observation $i$ are defined as those untreated observations that have the smallest difference in propensity score with respect to $i$. If we choose to use $n n$ nearest neighbors, we set $W_{i j}=\frac{1}{n n}$ for the observations that have been selected; for other observations we set $W_{i j}=0$. We applied the above method to both one nearest neighbor and five nearest neighbors.

When we used a "five nearest neighbors" matching estimator (without replacement), the following mean differences ( $t$-statistics in parentheses) were obtained: ${ }^{32}$

- GDP per capita growth: $-1.11(1.98)$

- GDP growth volatility: $1.18(2.84)$

In terms of GDP growth, these results strengthened the conclusions obtained from the treatment regressions reported in Table 3. Indeed, the matching estimator mean difference is still negative, but it is now statistically significant. The matching result for volatility confirms the treatment regression finding, and indicates that during the period under consideration dollarized countries have had more volatile growth than countries with a currency of their own. Notice that according to the matching results, the difference in volatility has been smaller than what is suggested by the treatment regression results (1.18 vs. 2.08).

\section{IV.2 Alternative Samples}

In the preceding section we analyzed whether dollarized economies had outperformed - in terms of GDP growth and volatility - countries with a currency of their

\footnotetext{
31 This assumes that there are no omitted variables problems in the estimation of the propensity used to select the nearest neighbors.

32 The propensity score equations were specified as those reported in the lower panel of Table 2.
} 
own. That is, in the results reported above, the "untreated group" is comprised of all countries with a domestic currency, independently of their exchange rate regime.

Many countries that have recently considered adopting a dollarized regime have, in fact, been countries that already had a pegged exchange rate regime - two such cases are Argentina (which ultimately rejected dollarization) and El Salvador (which adopted official dollarization). We can gain some insights on the differential performance in countries with dollarized and pegged exchange rate regimes by estimating treatment regression models where the "untreated group" is restricted to countries with a pegged exchange rate. In performing this analysis we use the classification of de facto exchange rate regimes proposed by Levy-Yeyati and Sturzenegger (2001). ${ }^{33}$ The results obtained in this case are reported in Table 3. As may be seen, in the growth equations the dollarization dummy is positive but insignificant. On the other hand, the dollarization dummy is significantly negative in the volatility equation; its point estimates, however, are lower than those reported in Table 2, where the untreated group included all countries with a currency of their own. Most of the other covariates have the expected sign and are significant at conventional levels. The results reported in Table 3, then, suggest that during the period under consideration, real economic performance in dollarized countries has not been better than in pegged exchange rate countries: growth has not been significantly different, while volatility has been somewhat higher in the dollarized countries. We conjecture that the reason for this result is that pegged rate countries still have some ability to use monetary policy in the short run to help accommodate external shocks.

\section{Concluding Remarks}

As a consequence of the emerging markets' currency crises of the 1990s, a number of economists have argued that the emerging economies should give up their domestic currencies, and become "strictly dollarized." Interestingly, there have been very few systematic comparative studies on the performance of countries that, indeed, do not have a currency of their own. Moreover, most of the literature on the subject has, in fact, been based on analyses of groups of countries strongly dominated by currency union

33 This classification uses cluster analysis on three variables to classify exchange rate regimes. The resulting classification is somewhat different than the traditional de jure classification from the International Monetary Fund. 
countries; these studies have included very few observations on "strictly dollarized" countries.

The purpose of this paper has been to analyze, from a comparative perspective, economic performance in strictly dollarized economies. A difficulty in performing this type of analysis refers to defining the "control group" with which to compare the performance of the dollarized countries. In this paper we tackled this issue by using the "treatment effects model" developed in the labor economics literature; this method allows us to jointly estimate the probability of being a "strictly dollarized country," and the effect of having this particular monetary regime on specific macroeconomic outcomes. Estimates using this technique yields results that are different from those obtained from simple comparisons using a large control group of all with-domestic-currency countries. More specifically, we found that dollarized countries have had a slightly lower rate of growth than countries with a domestic currency; this difference, however, is not statistically significant. We also found that GDP volatility has been significantly higher in dollarized economies, than in with-currency countries.

According to our results, the probability of being a dollarized country depends on regional, geographical, political and structural variables. More specifically, these results indicate that the probability of being a "dollarized" country is higher for very small both in terms of population and initial GDP --, not independent countries (or territories), that are very open, and have a low degree of credibility. In order to measure credibility we build an index as a composite of institutional, structural and economic variables.

Our analysis has not dealt with inflation. There is evidence, however, strongly indicating that dollarized countries have experienced a significantly lower rate of inflation than countries with independent monetary policy. Taken together, these results suggest that countries that give up their domestic currency, and officially dollarize their economies, face a trade off. They will have lower inflation, higher volatility and approximately the same rate of growth. 


\section{APPENDIX:}

\section{A Credibility Index}

In order to incorporate the role of political factors in the decision to adopt a hardpeg regime, we use principal components to construct a "credibility" index. This index contains two types of variables: (a) variables that are related to the ability to build and sustain credible monetary institutions; and (b) variables that are related to inflationary bias, or inflationary temptation. In the first set we include a dummy for countries that have inherited the French legal system, which according to La Porta et al. (1999, p. 231232 ) is related to weaker institutions. ${ }^{34}$ We have also included the number of years since the country's independence. Countries that have become independent more recently are less likely to have strong institutions. Finally, we also included a variable that measures political instability, defined by Kaufmann et al. (1999). Political instability is likely to be related to the inability to build strong institutions (it might also be related to inflation bias). On the inflation bias side we have included a dummy for exporters of non-fuel primary products, since these are generally underdeveloped countries that are more likely to use inflation to finance fiscal imbalances. Also, we include a variable that captures an "inflationary neighborhood effect." We defined this variable as the average rate of inflation in the ten nearest countries. It is well known that while Central America is traditionally a region of low inflation, the contrary applies to South America.

In order to build the credibility index we used a principal-components technique ${ }^{35}$. This technique captures the common variability of all the variables included. The index gives lower values to countries that inherited the French legal system (leg_french), obtained their independence more recently (indepy), experience more political instability (instability), are exporters of non-fuel primary products (exp_prim) and whose neighbors show larger rates of inflation (neigh_inf). In particular, our credibility index is calculated as follows ${ }^{36}$ :

\footnotetext{
${ }^{34}$ Also see Beck et al. (2002).

${ }^{35}$ On principal components see Green (2000).

${ }^{36}$ The corresponding eigenvalue is 1.43 and the principal component captures $26 \%$ of the total variance of the included varaibles.
} 
Credibility $_{k}=-0.38 * \operatorname{leg}_{\text {french }} \mathrm{k}+0.36 *$ indepy $_{\mathrm{k}}-0.66 *$ instability $_{\mathrm{k}}-0.49 *$ exp prim $_{\mathrm{k}}-$ $0.19 *$ neigh_inf ${ }_{\mathrm{k}}$.

The index has values that range from -5.24 to 3.16 , with a mean of 0.00 and a median of 0.03. A higher value of the index reflects a higher degree of credibility. Among the countries with the highest values are Denmark, France, Japan, Netherlands, Portugal, Sweden, Switzerland and the United States. Countries with low values are, among others, Angola, Belarus, Chad, Congo, Kenya, Sudan, Swaziland, Ukraine and Uganda. 


\section{REFERENCES}

Alesina, A. and R. Barro (2000), “Currency Unions”, NBER Working Paper, 7927.

Alesina, A., R.J. Barro and S. Tenreyro (2002). "Optimal Currency Areas" NBER Working Paper 9072.

Angrist, J. (2000). "Estimation of Limited Dependfent Variable Models with Dummy Endogenous regressors: Simple Strategies for Empirical Practice,” NBER TP \# 248.

Barro, R.J. (1996). “Determinants of Economic Growth: A Cross-Country Empirical Study”, NBER Working Paper 5698.

Barro, R.J. and Lee, J. (1996). "International Data on Educational Attainment: Updates and Implications", CID Working Paper 42.

Baro, R.J. and X. Sala-i-Martin (1995). Economic Growth, McGraw Hill

Beck, T., R. Levine and N. Loayza (2000). "Finance and the Source of Growth", Journal of Financial Economics 58, pp. 261-300.

Bernhard, W., Broz, J.L. and Clark, W.R. (2002). "The Political Economy of Monetary Institutions". International Organization, 56(4), pp. 693-723.

Blundell, R., A and Costa Dias, M. (2000), "Evaluation Methods for Non-Experimental data," Fiscal Studies, 21, 427-468.

Bogetic, Z. (2000). "Official Dollarization: Current Experiences and Issues", Cato Journal; 20(2), 179-213.

Calvo, G.A. (1999). “Fixed vs. Flexible Exchange Rates,” U. of Maryland Working Paper.

Cooper, R.W. and H. Kempf (2001). "Dollarization and the Conquest of Hyperinflation in Divided Societies", Federal Reserve Bank of Minneapolis Quarterly Review 25(3).

Corden W.M. (2002). Too Sensational: On the Selection of the Exchange Rate Regime, MIT Press

Dornbusch, R. (1982). "Stabilization Policies in Developing Countries: What Have We Learned?", World Development, 10(9), pp. 701-08.

Dornbusch, R. (2001). "Fewer Monies, Better Monies", American Economic Review; 91(2), 238-42. 
Edwards, S. (1999). "Exchange Rate Regimes, Capital Flows and Crisis Prevention," Presented at the NBER Conference on Capital Flows and Currency Crises

Edwards, S. (2001). "Dollarization: Myths and Realities", Journal of Policy Modeling 23(3), 249-65.

Edwards, S. and I.I. Magendzo, (2001).“Dollarization, Inflation and Growth” ”, NBER Working Paper 8671.

Edwards, S. and I.I. Magendzo, (2002). "Independent Currency Unions, Growth, and Inlfation", Monetary and Economic Studies, 20(1), pp.215-233.

Edwards, S. and I.I. Magendzo, (2003).“A Currency of One's Own? An Empirical Investigation on Dollarization and Independent Currency Unions", NBER Working Paper 9514.

Eichengreen, B. (2001). "What Problems Can Dollarization Solve?”, Journal of Policy Modeling 23(3), 267-77.

Eichengreen, B. and R. Haussmann (1999). "Exchange Rates and financial Fragility", paper presented at the IDB-OECD forum.

Engel, Ch. And A.K. Rose (2002), "Currency Unions and International Integration" Journal of Money, Credit and Banking 34(4).

Fischer, S. (1976). "Stability and Exchange Rate Systems in a Monetarist Model of the balance of payments," in R.,Z. Aliber, The Political Economy of Monetary Reform, McMillan, New York

Frankel, J.A. (1999); "No Single Currency Regime is Right for All Countries at at All Times", National Bureau of Economic Research Working Paper: 7338.

Frankel, J.A. and A.K. Rose (2002). "An Estimate of the Effect of Common Currencies on Trade and Income", Quarterly Journal of Economics, 117(2).

Freeman, J.R. (2002). "Competing Commitments: Technocracy and Democracy in the Design of Monetary Institutions”. International Organization, 56(4), pp. 889-910.

Frenkel, J.A. and A. Razin (1987). Fiscal Policies and Growth in the World Economy, MIT Press

Frieden, J.A. (2002). "Real Sources of European Currency Policy: Sectoral Interests and European Monetary Integration”. International Organization, 56(4), pp. 831-860.

Frieden, J.A. (2003). "The Political Economy of Dollarization" in E. Levy-Yeyati and F. Sturzenegger (Eds.) Dollarization, MIT Press 
Green, W.H. (2000). Econometric Analysis. Macmillan Publishing Company.

Ghosh, A., A. Gulde, J. Ostry and H. Wolf, (1995). "Does the Nominal Exchange Rate Regime Matter?” IMF Working Paper 95/121.

Goldfajn, I. and G. Olivares (2000). "Is Adopting Full Dollarization the Solution? Looking at the evidence", PUC-Rio Working Paper 416.

Heckman, J. (1978). "Dummy Endogenous Variables in a simultaneous Equation System”, Econometrica 46.

IMF (1997). "Exchange Rate Arrangements and Economic Performance in Developing Countries" Ch. 4 of World Economic Outlook, October.

Kaufmann, D., A. Kray and P. Zoido-Lobaton (1999). “Aggregating Governance Indicators”, World Bank Policy Research Department Working Paper No. 2195.

Klein, M.W. (2002). "Dollarization and Trade”, NBER Working Paper 8879.

La Porta, R., F. Lopez de Silanes, A. Shleifer and R. Vishny (1997). "Law and Finance", Journal of Political Economy106, pp. 1113-1155.

Leamer, E.E. (1997). "Access to Western Markets and Eastern Effort," in Salvatore Zecchini, ed., Lessons from the Economic Transition, Central and Eastern Europe in the 1990s, Dordrecht: Kluwer Academic Publishers, pp. 503-526.

Levy-Yeyeti, E. and F. Sturzenegger (2001). "To Float or to Trail: Evidence on the Impact of Exchange Rate Regimes", Universidad Torcuato di Tella.

Maddala, G.S. (1983). Limited-Dependant and Qualitative Variables in Econometrics. Cambridge University Press.

Mill, J.S. (1848). Principles of Political Economy, with some of their Applications to Social Philosophy. London: John W. Parker, West Strand.

Meade, J.E. (1950). The Balance of Payments.London: Oxford University.

Moreno-Villalaz, J.L. (1999) "Lessons from the Monetary Experience of Panama: A Dollar Economy with Financial Integration”, Cato Journal 18(3), 421-39.

Mundell, R.A. (1961). “A Theory of Optimum Currency Areas”, American Economic Review, 51(3).

Parrado, E. and A. Velasco (2002). "Optimal Interest Rate Policy in a Small Open Economy”, NBER Working Papers 8721. 
Persson, T. and G. Tabellini (2000). "Political economics: Explaining economic policy". Zeuthen Lecture Book Series. Cambridge and London: MIT Press.

Powell, A. and F. Sturzenegger (2000), “Dollarization: The Link Between Devaluation and Default Risk.” Working Paper, Universidad Torcuato di Tella, Buenos Aires, Argentina

Rose, A. (2000). “One Money, One Market: Estimating The Effect of Common Currencies on Trade", Economic Policy 15(30), 7-46.

Rose, A.K. and E. van-Wincoop (2001). "National Money as a Barrier to International Trade: The Real Case for Currency Union”, American Economic Review; 91(2), 386-90

Rosenbaum P.R. and D.B. Rubin (1983), "The Central Role of the Propensity Score in Observational Studies for Causal Effects”, Biometrika 70.

Sachs, J.D. (2000). "Globalization and Patterns of Economic Development", Weltwirtschaftliches Archiv/Review of World Economics 136(4).

Sachs, J. and A. Warner (1995) "Economic Reform and the Process of Global Integration," Brookings Papers on Economic Activity, 1, 1-188.

Venables, A.J., H. Overman and S. redding, (2002). "The Economic Geography of Trade, Production and Income" CEPR

Wooldridge, J.M. (2002). Econometric Analysis of Cross Section and Panel Data. MIT Press 


\section{Table 1}

\section{"Dollarized" Countries and Territories With Available Data}

USA

Liberia $^{\mathrm{I} *}$

Marshall Islands ${ }^{\text {I }}$

Micronesia Fed. States of ${ }^{\mathrm{I}}$

Palau ${ }^{\mathrm{I}}$

Panama ${ }^{\mathrm{I}}$

Puerto Rico

NEW ZEALAND

Cook Islands

\section{DENMARK}

FRANCE

Andorra I (also Spanish Peseta)
French Guiana
Guadeloupe
Martinique
Monaco I
Reunion

ITALY

San Marino ${ }^{\mathrm{I}}$
AUSTRALIA

Kiribati $^{\mathrm{I}}$

Tonga

Nauru Tuvalu ${ }^{\mathrm{I}}$

SWITZERLAND

Liechtenstein ${ }^{\mathrm{I}}$

BELGIUM

Luxembourg $^{\mathrm{I}}$

Greenland

*Dollarized until 1982.

${ }^{\mathrm{I}}$ Denotes that the country in question is independent at the time of this writing. Kiribati became independent in 1980; The Marshall Islands in 1987; Palau in 1995; and Tuvalu in 1979. 
TABLE 2

Growth, Volatility and Strict Dollarization:

A Treatment Effects Model

\begin{tabular}{|c|c|c|c|c|c|}
\hline & \multicolumn{3}{|c|}{ GROWTH } & \multicolumn{2}{|c|}{ VOLATILITY } \\
\hline & MODEL 1 & MODEL 2 & MODEL 3 & MODEL 4 & MODEL 5 \\
\hline$\overline{\log \left(\mathrm{GDP}_{0}\right)}$ & $\begin{array}{l}-0.460 \\
(-5.33)\end{array}$ & $\begin{array}{l}-0.405 \\
(-4.10)\end{array}$ & $\begin{array}{l}-0.432 \\
(-2.99)\end{array}$ & $\begin{array}{l}0.363 \\
(3.08)\end{array}$ & $\begin{array}{l}0.106 \\
(0.81)\end{array}$ \\
\hline OPEN & $\begin{array}{l}2.756 \\
(9.98)\end{array}$ & $\begin{array}{l}2.606 \\
(9.29)\end{array}$ & $\begin{array}{l}2.590 \\
(6.37)\end{array}$ & $\begin{array}{l}-2.608 \\
(-6.96)\end{array}$ & $\begin{array}{l}-2.236 \\
(-6.06)\end{array}$ \\
\hline TROPIC & $\begin{array}{l}0.034 \\
(0.05)\end{array}$ & $\begin{array}{l}-2.021 \\
(-1.88)\end{array}$ & $\begin{array}{l}-2.316 \\
(-1.49)\end{array}$ & $\begin{array}{l}1.875 \\
(2.03)\end{array}$ & $\begin{array}{l}4.174 \\
(2.98)\end{array}$ \\
\hline DUMMY_DOLL & $\begin{array}{l}0.511 \\
(0.88)\end{array}$ & $\begin{array}{l}0.445 \\
(0.78)\end{array}$ & $\begin{array}{l}0.580 \\
(0.71)\end{array}$ & $\begin{array}{l}2.076 \\
(2.72)\end{array}$ & $\begin{array}{l}2.761 \\
(3.72)\end{array}$ \\
\hline Constant & $\begin{array}{l}3.853 \\
(7.12)\end{array}$ & $\begin{array}{l}4.019 \\
(6.04)\end{array}$ & $\begin{array}{l}3.919 \\
(4.02)\end{array}$ & $\begin{array}{l}2.571 \\
(3.47)\end{array}$ & $\begin{array}{l}4.694 \\
(5.33)\end{array}$ \\
\hline EUROPE & ----- & $\begin{array}{l}-1.940 \\
(-4.20)\end{array}$ & $\begin{array}{l}-1.938 \\
(-2.88)\end{array}$ & ------ & $\begin{array}{l}0.992 \\
(1.64)\end{array}$ \\
\hline LAC & ------- & $\begin{array}{l}-0.695 \\
(-2.05)\end{array}$ & $\begin{array}{l}-0.724 \\
(-1.46)\end{array}$ & ------- & $\begin{array}{l}-0.606 \\
(-1.36)\end{array}$ \\
\hline MENA & ---- & $\begin{array}{l}-1.314 \\
(-3.08)\end{array}$ & $\begin{array}{l}-1.404 \\
(-2.25)\end{array}$ & - & $\begin{array}{l}3.058 \\
(5.44)\end{array}$ \\
\hline NORAM & 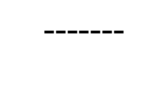 & $\begin{array}{l}-1.120 \\
(-1.42)\end{array}$ & $\begin{array}{l}-1.131 \\
(-0.98)\end{array}$ & ------- & $\begin{array}{l}-0.734 \\
(-0.71)\end{array}$ \\
\hline SASIA & --- & $\begin{array}{l}0.860 \\
(1.43)\end{array}$ & $\begin{array}{l}1.155 \\
(1.31)\end{array}$ & ------- & $\begin{array}{l}-2.198 \\
(-2.77)\end{array}$ \\
\hline AFRICA & ------ & $\begin{array}{l}-1.900 \\
(-5.27)\end{array}$ & $\begin{array}{l}-1.879 \\
(-3.54)\end{array}$ & ------ & $\begin{array}{l}-0.539 \\
(-1.13)\end{array}$ \\
\hline Log(POP) & $\begin{array}{c}-0.461 \\
(-20.26)\end{array}$ & $\begin{array}{c}-0.461 \\
(-20.26)\end{array}$ & $\begin{array}{l}-0.476 \\
(-8.69)\end{array}$ & $\begin{array}{l}-0.476 \\
(-8.69)\end{array}$ & $\begin{array}{l}-0.476 \\
(-8.69)\end{array}$ \\
\hline $\log \left(G D P_{0}\right)$ & $\begin{array}{l}-0.022 \\
(-0.54)\end{array}$ & $\begin{array}{l}-0.022 \\
(-0.54)\end{array}$ & $\begin{array}{l}-0.068 \\
(-0.69)\end{array}$ & $\begin{array}{l}-0.068 \\
(-0.69)\end{array}$ & $\begin{array}{l}-0.068 \\
(-0.69)\end{array}$ \\
\hline INDEP & $\begin{array}{l}-0.823 \\
(-8.68)\end{array}$ & $\begin{array}{l}-0.823 \\
(-8.68)\end{array}$ & $\begin{array}{l}-1.003 \\
(-4.09)\end{array}$ & $\begin{array}{l}-1.003 \\
(-4.09)\end{array}$ & $\begin{array}{l}-1.003 \\
(-4.09)\end{array}$ \\
\hline BORDER & $\begin{array}{l}0.264 \\
(2.33)\end{array}$ & $\begin{array}{l}0.264 \\
(2.33)\end{array}$ & $\begin{array}{l}0.347 \\
(1.26)\end{array}$ & $\begin{array}{l}0.347 \\
(1.26)\end{array}$ & $\begin{array}{l}0.347 \\
(1.26)\end{array}$ \\
\hline OPEN & $\begin{array}{c}1.232 \\
(11.77)\end{array}$ & $\begin{array}{c}1.232 \\
(11.77)\end{array}$ & $\begin{array}{l}1.315 \\
(5.24)\end{array}$ & $\begin{array}{l}1.315 \\
(5.24)\end{array}$ & $\begin{array}{l}1.315 \\
(5.24)\end{array}$ \\
\hline DISTANCE & $\begin{array}{l}0.112 \\
(1.01)\end{array}$ & $\begin{array}{l}0.112 \\
(1.01)\end{array}$ & $\begin{array}{l}0.108 \\
(0.41)\end{array}$ & $\begin{array}{l}0.108 \\
(0.41)\end{array}$ & $\begin{array}{l}0.108 \\
(0.41)\end{array}$ \\
\hline CREDIBILITY & $\begin{array}{l}-0.259 \\
(-4.84)\end{array}$ & $\begin{array}{l}-0.259 \\
(-4.84)\end{array}$ & $\begin{array}{l}-0.247 \\
(-1.86)\end{array}$ & $\begin{array}{l}-0.247 \\
(-1.86)\end{array}$ & $\begin{array}{l}-0.247 \\
(-1.86)\end{array}$ \\
\hline Constant & $\begin{array}{l}4.394 \\
(3.59) \\
\end{array}$ & $\begin{array}{l}4.394 \\
(3.59) \\
\end{array}$ & $\begin{array}{l}5.074 \\
(1.70) \\
\end{array}$ & $\begin{array}{l}5.074 \\
(1.70) \\
\end{array}$ & $\begin{array}{l}5.074 \\
(1.70) \\
\end{array}$ \\
\hline Number of obs & 3,966 & 3,966 & 720 & 720 & 720 \\
\hline Wald chi2 & 261.97 & 315.14 & 109.73 & 87.82 & 157.98 \\
\hline Prob > chi2 & 0.000 & 0.000 & 0.000 & 0.000 & 0.000 \\
\hline
\end{tabular}

* The upper panel contains the outcome equation. The lower panel contains the estimation of the treatment equation, or equation on the probability of being a "common currency country." The numbers in parentheses are z-statistics. 
TABLE 3

Strict Dollarization vs. Fixed Exchange Rates:

A Treatment Effects Model

\begin{tabular}{|c|c|c|c|c|c|}
\hline & \multicolumn{3}{|c|}{ GROWTH } & \multicolumn{2}{|c|}{ VOLATILITY } \\
\hline & MODEL 1 & MODEL 2 & MODEL 3 & MODEL 4 & MODEL 5 \\
\hline $\log \left(G P_{0}\right)$ & $\begin{array}{l}-0.509 \\
(-2.92)\end{array}$ & $\begin{array}{l}-0.409 \\
(-1.93)\end{array}$ & $\begin{array}{l}-0.408 \\
(-1.54)\end{array}$ & $\begin{array}{l}0.452 \\
(2.27)\end{array}$ & $\begin{array}{l}0.004 \\
(0.02)\end{array}$ \\
\hline OPEN & $\begin{array}{l}1.495 \\
(2.80)\end{array}$ & $\begin{array}{l}1.519 \\
(2.56)\end{array}$ & $\begin{array}{l}1.757 \\
(2.14)\end{array}$ & $\begin{array}{l}-2.454 \\
(-3.72)\end{array}$ & $\begin{array}{l}-2.232 \\
(-3.07)\end{array}$ \\
\hline TROPIC & $\begin{array}{l}-3.002 \\
(-1.95)\end{array}$ & $\begin{array}{l}-6.782 \\
(-2.80)\end{array}$ & $\begin{array}{l}-4.174 \\
(-1.37)\end{array}$ & $\begin{array}{l}4.177 \\
(2.34)\end{array}$ & $\begin{array}{l}6.082 \\
(2.25)\end{array}$ \\
\hline DUMMY_DOLL & $\begin{array}{l}0.605 \\
(1.21)\end{array}$ & $\begin{array}{l}0.463 \\
(0.86)\end{array}$ & $\begin{array}{l}0.384 \\
(0.55)\end{array}$ & $\begin{array}{l}1.270 \\
(2.09)\end{array}$ & $\begin{array}{l}1.632 \\
(2.64)\end{array}$ \\
\hline Constant & $\begin{array}{l}3.565 \\
(3.17)\end{array}$ & $\begin{array}{l}3.162 \\
(2.28)\end{array}$ & $\begin{array}{l}2.771 \\
(1.55)\end{array}$ & $\begin{array}{l}1.936 \\
(1.49)\end{array}$ & $\begin{array}{l}6.403 \\
(4.04)\end{array}$ \\
\hline EUROPE & ------ & $\begin{array}{l}-2.864 \\
(-2.46)\end{array}$ & $\begin{array}{l}-1.355 \\
(-0.88)\end{array}$ & ------ & $\begin{array}{l}0.406 \\
(0.30)\end{array}$ \\
\hline LAC & ------- & $\begin{array}{l}-0.607 \\
(-1.02)\end{array}$ & $\begin{array}{l}0.026 \\
(0.03)\end{array}$ & ------- & $\begin{array}{l}-1.380 \\
(-1.97)\end{array}$ \\
\hline MENA & -- & $\begin{array}{l}-1.636 \\
(-1.93)\end{array}$ & $\begin{array}{l}-0.352 \\
(-0.33)\end{array}$ & - & $\begin{array}{l}1.375 \\
(1.46)\end{array}$ \\
\hline NORAM & 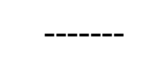 & - & ------- & - & ------- \\
\hline SASIA & & $\begin{array}{l}0.584 \\
(0.38)\end{array}$ & $\begin{array}{l}1.748 \\
(1.01)\end{array}$ & ------' & $\begin{array}{l}-3.640 \\
(-2.36)\end{array}$ \\
\hline AFRICA & ------ & $\begin{array}{l}-1.738 \\
(-2.66)\end{array}$ & $\begin{array}{l}-0.901 \\
(-1.05)\end{array}$ & ------ & $\begin{array}{l}-2.529 \\
(-3.31)\end{array}$ \\
\hline $\log (\mathrm{POP})$ & $\begin{array}{l}-1.081 \\
(-12.91)\end{array}$ & $\begin{array}{c}-1.081 \\
(-12.91)\end{array}$ & $\begin{array}{l}-1.306 \\
(-4.81)\end{array}$ & $\begin{array}{l}-1.306 \\
(-4.81)\end{array}$ & $\begin{array}{l}-1.306 \\
(-4.81)\end{array}$ \\
\hline $\log \left(G D P_{0}\right)$ & $\begin{array}{l}-0.726 \\
(-5.60)\end{array}$ & $\begin{array}{l}-0.726 \\
(-5.60)\end{array}$ & $\begin{array}{l}-1.029 \\
(-2.79)\end{array}$ & $\begin{array}{l}-1.029 \\
(-2.79)\end{array}$ & $\begin{array}{l}-1.029 \\
(-2.79)\end{array}$ \\
\hline INDEP & $\begin{array}{l}-2.765 \\
(-9.66)\end{array}$ & $\begin{array}{l}-2.765 \\
(-9.66)\end{array}$ & $\begin{array}{l}-3.643 \\
(-4.13)\end{array}$ & $\begin{array}{l}-3.643 \\
(-4.13)\end{array}$ & $\begin{array}{l}-3.643 \\
(-4.13)\end{array}$ \\
\hline BORDER & $\begin{array}{l}1.240 \\
(3.07)\end{array}$ & $\begin{array}{l}1.240 \\
(3.07)\end{array}$ & $\begin{array}{l}1.654 \\
(1.56)\end{array}$ & $\begin{array}{l}1.654 \\
(1.56)\end{array}$ & $\begin{array}{l}1.654 \\
(1.56)\end{array}$ \\
\hline OPEN & $\begin{array}{c}3.694 \\
(12.17)\end{array}$ & $\begin{array}{c}3.694 \\
(12.17)\end{array}$ & $\begin{array}{l}4.892 \\
(4.99)\end{array}$ & $\begin{array}{l}4.892 \\
(4.99)\end{array}$ & $\begin{array}{l}4.892 \\
(4.99)\end{array}$ \\
\hline DISTANCE & $\begin{array}{l}-0.350 \\
(-1.03)\end{array}$ & $\begin{array}{l}-0.350 \\
(-1.03)\end{array}$ & $\begin{array}{l}-0.365 \\
(-0.41)\end{array}$ & $\begin{array}{l}-0.365 \\
(-0.41)\end{array}$ & $\begin{array}{l}-0.365 \\
(-0.41)\end{array}$ \\
\hline CREDIBILITY & $\begin{array}{l}-0.815 \\
(-6.63)\end{array}$ & $\begin{array}{l}-0.815 \\
(-6.63)\end{array}$ & $\begin{array}{l}-0.994 \\
(-2.72)\end{array}$ & $\begin{array}{l}-0.994 \\
(-2.72)\end{array}$ & $\begin{array}{l}-0.994 \\
(-2.72)\end{array}$ \\
\hline Constant & $\begin{array}{c}23.498 \\
(5.72) \\
\end{array}$ & $\begin{array}{c}23.498 \\
(5.72) \\
\end{array}$ & $\begin{array}{r}29.007 \\
(2.51) \\
\end{array}$ & $\begin{array}{r}29.007 \\
(2.51) \\
\end{array}$ & $\begin{array}{r}29.007 \\
(2.51) \\
\end{array}$ \\
\hline Number of obs & 1,170 & 1,170 & 226 & 226 & 226 \\
\hline Wald chi2 & 175.38 & 189.96 & 44.85 & 67.48 & 100.61 \\
\hline Prob > chi2 & 0.000 & 0.000 & 0.000 & 0.000 & 0.000 \\
\hline
\end{tabular}

* The upper panel contains the outcome equation. The lower panel contains the estimation of the treatment equation, or equation on the probability of being a "common currency country." The numbers in parentheses are z-statistics. 